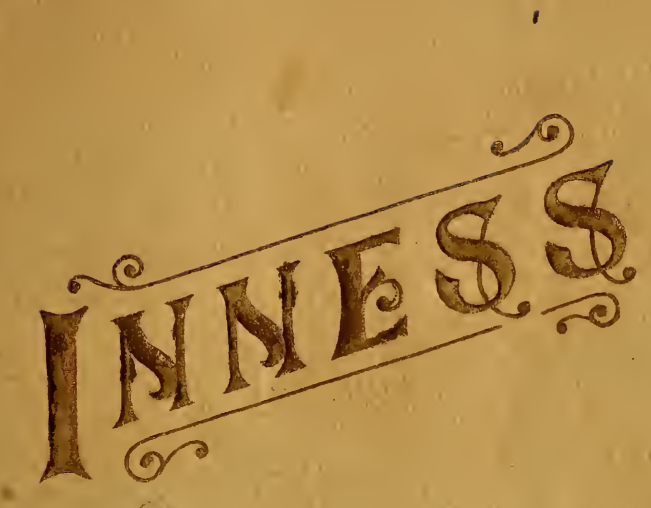

a.

$\because$ 

Fifth Avenue Art Galleries 366 FIFTH AVENUE

JAMES P. SILO. - - - AUCTIONEER.

\section{EXECUTOR'S SALE}

CATALOGUE

$\mathrm{OF}$

\section{PAINTINGS}

BY THE LATE

\section{GEORGE INNESS, N. A.}

ON FREE EX XHIEITION

From Monday, February 8th, until day of sale AT THE

FIFTH AVENUE AR'T GALLERIES 366 FIFTH AVENUE.

FOR SALE,

On Thursday, Friday and Saturday February i th, I 2 th and I $3^{\text {th }}$ at 8.15 o'clock.

\section{$[1904]$}




\section{CONDITIONS OF SALE}

I. The highest bidder to be the buyer, and if any dispute arise between two or more bidders, the lot so in dispute shall be immediately put up again and resold

2. The purchasers to give their names and addresses and to pay down a cash deposit, or the whole of the purchase money, if required, in default of which the lot or lots so purchased to be immediately put up again and resold.

3. The lots to be taken away at the buyer's expense and risk upon the conclusion of the sale and the renainder of the purchase money to be absolutely paid or otherwise settled for to the satisfaction of the auctioneer, on or before delivery; in default of which the undersigned will not hold himself responsible if the lots be lost, stolen, damaged or destroyed, but they will be left at the sole risk of the purchaser.

4. The sale of any article is not to be set aside on account of any error in the description. All articles are exposed for public exhibition one or more days and are sold just as they are, without recourse.

5. To prevent inaccuracy in delivery, and iuconvenience in settlement of the purchases, no lot can on any account be removed during the sale.

6. If, for any cause, an article purchased cannot be delivered in as good condition as the same may have been at the time of its sale, or should any article purchased thereafter be stolen or misdelivered, or lost, the undersigned is not to be held liable in any greater amount than the price bid by the purchaser.

7. Upon failure to comply with the above conditions, the money deposited in part payment shall be forfeited, all lots uncleared within the time aforesaid shall be resold by public or private sale, witliout further notice, and the deficiency, if any, attending such re-sale shall be made good by the defaulter at this sale, together with all charges attending the same. This condition is with out prejudice to the right of the auctioneer to enforce the contract made at this sale, without such re-sale if he thinks fit.

JAMES F. SILO, Auctioneer. 


\section{NOTE.}

The paintings enumerated in this Catalogue belong to the Estate of the late Mrs. Elizabeth Inness, the widow of George Inness, America's greatest landscape painter. Most of these paintings have been given by $\mathrm{Mr}$. Inness to Mrs. Inness with the express desire that they should not be disposed of during her life time; it is therefore gratifying to know that some of the most superb examples of this celebrated master will be available to the collectors and amateurs.

Mr. James P. Silo has been instructed to sell each and every picture without reservation of any kind.

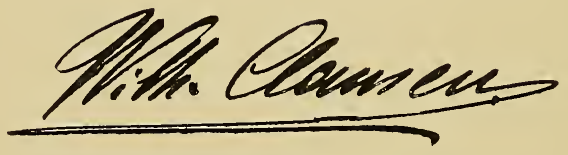

Manager for the Inness Estate 



\section{GEORGE INNESS.}

"No European school ever produced finer work than he put forth, and not the least of his services to his country will be seen to be the impetus he gave, and will continue to give, to the development of our national art. The art of the late George Inness is one of those fine revelations of a gifted individuality which is at once a deiight and a stimulus to honor. It carries the observer into the atmosphere of noble ideals and adequate expression which only a master can create, and it there awakens sympathies which only a master imbued with the spirit of nature can ever touch." -New York Tribune.

"His art was his life, and he never faltered for a moment in his absolute fidelity to noble ambitions or the highest aims. It stands for all that is good; it is manly, vigorous and honest, and has the true ring that betokens the highest aspirations and the best impulses. The fame of the late George Inness as the first of American landscape painters rests on a very firm foundation. Both painter and laynuan have long since admitted his position."-Nere York Times.

"It may be said in all safety that not again in this century will so impressive an exhibition of landscapes of any one man's painting be made as is found in this one of George Inness's."-The Post.

"No American painter has appeared at the time of his death to hold a higher place in the realm of art." '-- The Sun

"The result stands as a most impressive and convincing proof of the splendid breadth and vigor and poetic force which were the dominant features of this artist's methods."-Mail and Express. 
"George Inness had the rare gift of putting his own subjective appreciation into the landscapes which he placed upon canvas. He was no imitator, but his method was the same as that of Corot. A Freuch critic, pointing to a fine woodland sunset, once said: 'How glorious that would be if only Corot had painted it.' This was a true criticism. Corot would have seen what other people could not. He would have selected from the natural effects. He would have brought them home to whoever looked at his work. This is the rare power which Inness had."-New York Evening Sun.

"He loved nature, and sympathized with her in her moods. He transferred these to the canvas with a poetic touch which almost idealized the scenes he found so dear to him. He painted atmosphere with remarkable success. There was no problem too difflcult or too complicated for him to attempt. Whether the phase was that of daytime or dark, sunlight or moonlight, the calm of noon, the haze of daybreak, or the glow of sunset, it stood revealed and expressed in supreme truth and beauty." -New York World.

"Mr. Inness was a man of most inpressive origin. ality, a draughtsman of force, and a colorist of great richness and brilliancy. He painted atmosphere, both sunshine and storm, with signal success, and there is in his work a vigor and fiery manner of handling the pigment that is singularly fascinating. The artist, at the time of painting, knew exactly what he wanted to do, although he was foud of working on canvases until their whole aspect was changed." - New York Herald.

"His art is entirely his own, and does not contain a hint of the succession of landscape painters. It is reminiscent of nothing but nature, of which it represents every mood, every season and every time of day. So 
rich is his treasury of Nature's secrets, so poetic and fertile his brain, so great his power of execution, that although his output is probably as large as that of any other living artist, he never repeats himself, never paints twice just the same mood of nature, the same atmosphere or envelope."-The Century.

"Among his contemporaries, George Inness towered as a giant. He was not a genius of that class which, having gained its zenith remains fixed there or falls into declining grooves. His was a fire which age could not wither nor custom stale, and even as time sopped his vital forces, he grew even greater, younger, and more powerful in the vital spirit of his art." - The Collector.

"George Inness's landscapes are of the best painted in our time and country, in many instances of the best in any time and country, because of the qualities of temperament with which the artist was endowed. Probably there is at least no landscape painter now living whose works, if brought together, would stand the test of comparison with a complete collection of Inness's pictures--none who would equal him in the impression he gives of abounding and intense vitality. There is in all his representative paintings a rich, full, pulsing life, which testifies to his wonderful power of infusing his own exuberant spirit into the inanimate canvas, and making it breathe the breath of natnre. And so in an exceptionally emphatic sense his works live after hin. So long as they endure an Inness means, not a dead copy of nature, but a living embodiment, in which the sun shines with a true and grateful warmth, the breeze as truly whispers among the leaves and herbage, the clouds float buoyantly aloft, or lower over the earth with the grim menace of approaching storm, and all is movenent, animation and life."-Boston Transcript. 
"Let us do reverence to our own. Inness felt the breath of the tidal wave of his glory; would that he had been spared to feel himself ride more proudly upon its creast."-Boston Post.

"He was the greatest landscape painter America ever produced, and the greatest landscape painter of his time in the worlf. He has left America a great inheritancehis works, his name, his fame-these will continue to shed lustre on her through centuries to cone." - Once a Week.

"Certainly there are none anong either the Germans, French or Dutch who are painting landscapes at this time with the boldness, freedom and originality that are traits of Mr. Inness's work."-Brooklyn Eagle.

"An American artist of the first distinction whose nerit has received intentiational recognition by the placing of his pictures in public and private collections in Europe, as well as in his own country."'-Leslie's Weekly.

"The paintings of Inness will long perpetuate his fame, for he belonged to the high order of minds, which draw the patent of their rank from no school, but from nature direct."-Boston Herald.

"Mr. George Inness is not alone the greatest of the American landscape painters, but he is one of the fore. most landscape painters of the world."-Benjamm Constint. 


\section{CATALOGUE}

\section{FIRST EVENING'S SALE}

Thursday Evening, February 11th,

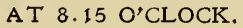

ALEXANDRIA BAY.

$16 \times 20$

2

THE SISTERS.

I $6 \times 20$

3

ROBBERS' CAVE.

$16 \times 20$ 
4

SACRED GRAVE, CAMPAGNA, ROME.

$$
12 \frac{1}{4} \times 18
$$

1873

$$
5
$$

ITALIAN TYROL.

$$
261 / 2 \times 333 / 4
$$

6

MARLBOROUGH ON HUDSON.

$$
131 / 2 \times 181 / 4
$$

$$
\tau
$$

MONTCLAIR, N. J.

$$
\begin{gathered}
\text { Sketch } \\
121 / 4 \times 18
\end{gathered}
$$


8

ALEXANDRIA BAY ON ST. LAWRENCE RIVER.

$$
\text { I } 6 \times 24
$$

1878

$$
9
$$

MEDFIELD, MASS.

$$
13^{1 / 2} \times 19^{1 / 2}
$$

IO

NORTH CONWAY, WHITE MOUNTAINS Sketch

$$
131 / 2 \times 183 / 4
$$

\section{I}

ALBANO, ITALY.

$$
30 \times 45
$$


MONTCLAIR, N.J.

Sketch

$51 / 2 \times 9$

$$
\text { I } 3
$$

NEAR MILTON.

$51 / 2 \times 87 / 8$

$$
\text { I } 4
$$

NEW JERSEY LANDSCAPE.

$$
13 \frac{3}{4} \times 19
$$

I 5

MONTCLAIR, N. J.

$$
16 \times 20
$$


I 6

TARPON SPRINGS, FLORIDA.

I $81 / 2 \times 241 / 2$

1890

\section{7}

NEW ENGLAND LANDSCAPE.

$91 / 8 \times 14$

I 8

NIAGARA.

$30 \times 45$

I 9

ITALY.

$93 / 8 \times$ I $23 / 4$ 


\section{0}

MONTCLAIR, N. J.

$9 \mathrm{I} / 2 \times 14 \mathrm{I} / 8$

ALEXANDRIA BAY ON ST. LAWRENCE RIVER.

$$
16 \times 24
$$

MILTON-ON-THE-HUDSON.

$$
91 / 4 \times 13
$$

$$
23
$$

NORTH CONWAY.

$$
9 \frac{x}{4} \times \quad \text { I } 4
$$




\section{4}

\section{LONG ISLAND LANDSCAPE}

Sketch

$53 / 4 \times 83 / 4$

25

MOUNT WASHINGTON.

$143 / 4 \times 183 / 4$

26

ON THE ST. LAWRENCE, ALEXANDRIA BAY.

$12 \frac{1}{4} \times 18$

DURHAM, CONN.

I $2 \times 173 / 4$ 


\section{8}

POMPTON, N. J.

$$
93 / 4 \times 14 \frac{1}{2}
$$

LEEDS, CATSKILLS SKETCH.

$$
\begin{aligned}
& \text { Sketch } \\
& 91 / 4 \times 13
\end{aligned}
$$

$$
30
$$

NORTH CONWAY, N. H.

$$
12 \times 181 / 4
$$

$$
31
$$

ALEXANDRIA BAY ON ST. LAWRENCE.

$$
16 \times 24
$$




\section{2}

MILTON-ON-THE-HUDSON.

$$
30 \times 35
$$

33

ITALIAN TYROL.

$$
261 / 4 \times 371 / 2
$$

\section{4}

MILTON-ON-THE-HUDSON.

$$
\text { I6 } \times 24
$$

\section{5}

LONG ISLAND LANDSCAPE.

$$
63 / 4 \times 101 / 2
$$




$$
36
$$

LATE AFTERNOON, MONTCLAIR.

$$
8 \times 12
$$

37

MILTON-ON-THE-HUDSON.

I $2 \times 18$

38

SPRING AT MONTCLAIR.

$$
111 / 2 \times 171 / 2
$$

39

IMPRESSION.

$51 / 2 \times 85 / 8$ 


$$
40
$$

PORTA D'ANZIO, ITALY.

$$
9^{1 / 2} \times 13
$$

$$
4 \text { I }
$$

\section{DEERHILL, CORNWALL.}

$$
9 \frac{1}{4} \times 12 \frac{1}{4}
$$

42

\section{EARLY AUTUMN.}

$$
\text { I } 8 \times 23
$$

$$
\begin{gathered}
43 \\
\text { WOOD INTERIOR. }
\end{gathered}
$$

$$
16 \times 23 \frac{1}{2}
$$




\section{4 \\ MEDFIELD, MASS.}

$15 \times 20$

45

ETRETAT, NORMANDY, FRANCE.

$$
63 / 4 \times 101 / 2
$$

$$
46
$$

MONTE LUCIA, ITALY.

$$
\text { I } 1 / 2 \times 171 / 4
$$

47

MEDFIELD, MASS.

$$
101 / 2 \times 14 \frac{1}{2}
$$




\section{8}

\section{SCENE A'T ITALY.}

$91 / 4 \times 123 / 4$

49

TROUT STREAM, NORTH CONWAY.

$131 / 4 \times 17$

50

IN THE GREEN MOUNTAINS.

$$
9^{1 / 4} \times 131 / 8
$$

$$
5 \text { I }
$$

IN THE CATSKILLS.

$$
9 \times 14
$$


52

MONTCLAIR.

$20 \times 30$

53

NORTH CONWAY.

$12 \times 18$

54

PORTO D'ANZIO, ITALY.

$13 \times 26$

55

ETRETAT, NORMANDY, FRANCE.

1874

$10 \times 17$ 


$$
56
$$

DURHAM, CONN.

$$
171 / 2 \times 221 / 2
$$

\section{7}

\section{ETRETAT, NORMANDY, FRANCE.}

$$
18 \times 26
$$

$$
58
$$

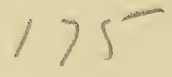

ITALIAN VIEW.

$$
12 \times 173 / 4
$$

59

IN THE CATSKILLS.

$$
8 \times \simeq 13 / 4
$$

60

MONTCLAIR, N. J.

$$
13 \times 18 \frac{1}{2}
$$




\section{SECOND EVENING'S SALE}

Friday Evening, February 12th,

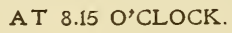

$$
6 \text { I }
$$

BARBARINO PINES, ALBANO, ITALY.

$$
173 / 4 \times 251 / 2
$$

62

ETRETAT, NORMANDY, FRANCE.

$$
12 \times \quad 173 / 4
$$

1874

63

MEDFIELD, MASS.

$$
\text { IO X I } 4 \frac{1}{2}
$$


64

LATE SUNSET.

$9 \frac{x}{4} \times$ I 2

65

WOOD INTERIOR, MONTCLAIR

$25 \times 30$

66

MONTCLAIR, N. J.

$8 \times 121 / 4$

67

SHAWANGUNK MOUNTAINS.

I I $3 / 4 \times \quad$ I $83 / 4$ 
68

\section{VIEW IN ITALY.}

$18 \times 26$

69

APPLE ORCHARD, MONTCLAIR, N. I.

$$
12 \times 18
$$

$$
70
$$

MONTCLAIR, N. J.

$$
12 \times 173 / 4
$$

$$
7 \mathrm{I}
$$

PORTA D'ANZIO, ITALY.

$$
91 / 2 \times 13
$$


72

MONTCLAIR.

$$
19^{1 / 2} \times 35
$$

\section{3}

SUNSET, MONTCLAIR.

$$
9 \times 12
$$

$$
74
$$

\section{PERUGIA, ITALY.}

$$
7 \times 101 / 2
$$

75

ETRETAT, NORMANDY, FRANCE.

$$
18 \times 26
$$




$$
76
$$

\title{
IN THE ADIRONDACKS.
}

\author{
IO $\times 14$
}

\section{7}

MEDFIELD, MASS.

$$
73 / 4 \times 13 \frac{1}{2}
$$

$$
78
$$

\section{MILTON-ON-THE-HUDSON}

\section{Sketch}

$$
20 \times 23^{1 / 2}
$$

$$
79
$$

NEAR PEEKSKILL, N. Y.

$$
\text { II } 1 / 4 \times 15
$$


80

SKETCH FROM NATURE.

$$
9 \mathrm{I} / 4 \times 14
$$

8 [

GREENE MOUNTAINS.

$$
9 \times 14
$$

82

AQUEDUCT NEAR ROME, ITALY.

$$
9 \times 123 / 4
$$

83

HASTINGS, N. Y.

$$
9 \times 133 / 4
$$




$$
\begin{gathered}
84 \\
\text { ITALY. } \\
\text { I } 5 \times 26 \\
85
\end{gathered}
$$

MILTON-ON-THE-HUDSON.

$$
27 \times 22
$$

$$
86
$$

NORTH CONWAY, WHITE MTS., N. H.

$$
171 / x \times \text { II } 3 / 4
$$

$$
87
$$

MONTCLAIR, N. J.

$$
73 / 4 \times 91 / 2
$$


88

WOOD INTERIOR, MONTCLAIR, N J.

$$
14 \times 18
$$

89

MOUNT WASHINGTON, NORTH CONWAY, N. H.

$$
12 \times 17 \frac{1}{4}
$$

90

LEEDS, N. Y.

$$
\text { I } 13 / 4 \times 17 \frac{1}{4}
$$

9I

LANDSCAPE.

$$
153 / 4 \times 233 / 4
$$




$$
9^{2}
$$

ALBANO, ITALY.

$$
171 / 2 \times 251 / 2
$$

93

ALBANO, ITALY.

$$
103 / 4 \times 16
$$

$$
94
$$

THE VETERANS RETURN.

$$
22 \times 27
$$

$$
95
$$

HASTINGS-ON-THE-HUDSON.

$$
113 / 4 \times 17
$$




\section{6}

ALBANO, ITALY.

$$
\text { I } 03 / 4 \times \text { I } 6
$$

\section{7}

\section{DURHAM, CONN.}

$9 \times 12 \frac{1}{4}$

$$
98
$$

\section{SUNSET TIME, MILTON.}

$$
\text { I9 } \times 24
$$

99

ITALY.

$$
14 \frac{1}{2} \times 21 \frac{1}{2}
$$


IOO

WALLKILL VALLEY.

$81 / 2 \times 24$

I O I

MILTON-ON-THE-HUDSON.

I $5 \times 253 / 4$

$\mathrm{IO} 2$

SHAWANGUNK MOUNTAINS.

I $4 \times 2$ I

103

CORNWALL, N. Y.

$91 / 4 \times 131 / 4$ 


$$
\text { IO4 }
$$

CATSKILLS, N. Y.

$$
91 / 4 \times 133 / 8
$$

$$
\text { IO5 }
$$

HACKENSACK MEADCWS.

$$
91 / 4 \times 133 / 4
$$

$$
\text { I } 06
$$

\section{PALISADES-ON-THE-HUDSON.}

$$
91 / 4 \times 14
$$

$$
\text { IO7 }
$$

POMPTON, N. J.

$$
91 / 4 \times 13
$$




\section{08 \\ GREY EVENING. \\ $173 / 4 \times 163 / 4$ \\ IO9 \\ LANDSCAPE.}

$20 \times 30$

I IO

MILTON-ON-THE-HUDSON.

$20 \times 30$

I I I

TWO RAINBOWS, MONTCLAIR.

Sketch

$20 \times 30$ 
I I 2

MIONTCLAIR MEADOWS.

IO $\times 14 \frac{1}{2}$

I 13

THE AFTER-GLOW, ITALY.

$133 / 4 \times 193 / 4$

I I 4

EVENING.

$16 \times 24$

I I 5

ERIE VALLEY.

$71 / 2 \times 113 / 4$ 


\title{
I I 6 \\ EVENING GLOW.
}

$22 \times 36$

\author{
I I 7 \\ DELAWARE VALLEY.
}

$183 / 4 \times 241 / 2$

I 18

NORTH CONWAY, WHITE MOUNTAINS, N. H.

$$
17 \frac{1}{2} \times 22
$$

I I 9

IN THE ADIRONDACKS.

$$
163 / 4 \times 221 / 4
$$




\section{20 \\ MONTCLAIR.}

$33^{1 / 2} \times 4^{1 / 2}$

I 2 I

THE ORCHARD, MONTCLAIR, N. J.

$2.2 \times 36$

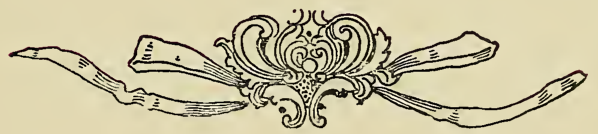




\section{THIRD EVENING'S SALE}

\section{Saturday Evening, Eebruary 13th, A T $8.15 \mathrm{O}^{\prime} \mathrm{CLOCK}$.}

I 22

MILTON.

$15 \times 18$

123

LAKE NAME, ITALY.

I $2 \times$ I 8

I 24

IN THE HAMMOCK

Sketch

$61 / 2 \times 10$ 
OI.D AQUEDUCT, CAMPAGNA, ROME, ITALY.

$$
81 / 4 \times 123 / 4
$$

\section{26}

\section{PALISADES-ON-THE-HUDSON.}

$$
20 \times 30
$$

\section{27 \\ SUNSET

\author{
sketch
} \\ $10 \times 133 / 4$}

\section{28}

\section{A VIEW IN CUBA.}

The only sketch Mr. Inness made in Cuba.

$$
19 \times 23 \frac{1}{4}
$$




\section{29 \\ ROUNDOUT VALLEY.}

$$
9^{1 / 4} \times 14
$$

\section{0}

WOOD INTERIOR AT HASTINGS

$91 / 4 \times 14$

I 3 I

ITALIAN LANDSCAPE.

$18 \times 25 \pi / 2$

I 32

MONTCLAIR.

$10 \times 15$ 


\section{33}

MONTCLAIR, N. J.

$$
9 \times 15
$$

$$
\text { I } 34
$$

THE INVALID.

$$
91 / 2 \times 13
$$

$$
\text { I } 35
$$

\section{IN THE WOODS AT HASTINGS.}

$$
\text { I } 53 / 4 \times 193 / 4
$$

$$
\text { I } 36
$$

\section{MONTCLAIR.}




\section{37}

AUTUMN, MONTCLAIR.

$$
20 \times 30
$$

I 38

\section{TIVOLA, ITALY.}

$$
\text { I I } 3 / 4 \times 14 \frac{1}{4}
$$

$$
\text { I } 39
$$

SARCO VALLEY, NORTH CONWAY.

$$
9^{1 / 2} \times 133 / 4
$$

$$
\text { I } 40
$$

LAKE NAME, ITALY.

$$
\text { I } 2 \times \quad \text { I } 8
$$




\section{4 I}

MEDFIELD, MASS.

$$
\text { II } 1 / 4 \times 153 / 4
$$

I 42

NORTH CONWAY.

$12 \times 18$

\section{DELAWARE VALLEY.}

$$
\text { I7 } \times 25
$$

\section{44}

DELAWARE VALLEY.

$$
15 \frac{1}{2} \times 24
$$




\section{5}

BARBARINO PINES, ALBANO, ITALY.

$$
73 / 4 \times 253 / 4
$$

$$
146
$$

HARTFORD, CONN.

$$
14 \times 20
$$

\section{7}

EARLY SPRING ON PASSAIC RIVER.

$$
20 \times 30
$$

$$
148
$$

EARLY AUTUMN.

$$
\text { I } 8 \times 26
$$


SCENE FROM "TEMPEST"

(SHAKESPEARE).

$$
7^{1 / 2} \times 9^{1 / 2}
$$

$$
\text { I } 5 \mathrm{O}
$$

NATURAL BRIDGE, ETRETAT, NORMANDY, FRANCE.

$$
18 \times 26
$$

I 5 I

SUNSET IN THE WOODS, MONTCLAIR.

$$
17 \times 30
$$

I 52

SUNSET, POMPTON, N. J.

$$
20 \times 30
$$


I 53

MONTCLAIR, N. J.

I $6 \times 24$

I 54

POMPTON, N. J.

$9^{1 / 4} \times 14$

I 55

SYMPHONY.

$24 \times 36$

I 56

MONTCLAIR.

$24 \times 36$ 


\section{57}

HASTINGS.

$$
\text { I } 53 / 4 \times 233 / 4
$$

158

\section{MILTON-ON-THE-HUDSON.}

$$
\text { I6 } \times 24
$$

I 59

MONTCLAIR, N. J.

$$
18 \times 26
$$

160

AUTUMN, MONTCLAIR.

$$
12 \times 18
$$




\section{6 I \\ MONTCLAIR.}

$$
\text { I } 6 \times 24
$$

162

PERUGIA, ITALY.

$$
20 \times 30
$$

163

SUNSET, MONTCLAIR.

$$
163 / 4 \times 24
$$

$$
\text { I } 64
$$

TARPON SPRINGS, FLORIDA. 
I 65

MONTCLAIR SUNSET.

$45 \times 30$

I 66

MILTON.

$161 / 2 \times 171 / 2$

I 67

NEAR PERUGIA.

I $13 / 4 \times 171 / 4$

I 68

TIVOLA, ITALY.

I $2 \times 14$ 
I 69

DURHAM, CONN.

$18 \times 26$

I 70

SACRED GROVE, CAMPAGNA, ROME, ITALY.

$$
20 \times 30
$$

I 7 I

EARLY AUTUMN, MONTCLAIR.

$30 \times 45$

1894

I 72

AFTER A SPRING SHOWER AT MONTCLAIR.

$$
391 / 2 \times 35
$$




\title{
173
}

\section{EVENING.}

$$
18 \times 26
$$

\author{
I 74 \\ MONTCLAIR, N. J. \\ $9^{1 / 2} \times 131 / 8$ \\ 1 75
}

MARLBOROUGH.

$12 \times 15$

176

SUNSET, MONTCLAIR.

$$
16 \times 24
$$




\section{7}

ITALIAN TYROL.

$$
193 / 4 \times 293 / 4
$$

I 78

DURHAM VALLEY.

$$
16 \times 24
$$

179

ALBANO, ITALY.

$$
181 / 2 \times 25
$$

\section{80}

EARLY SPRING, MONTCLAIR.

$$
16 \times 20
$$




\section{81}

\section{EVENING, MONTCLAIR.}

$$
24 \times 16
$$

$$
\text { I } 82
$$

\section{WINTER IN ENGLEWOOD.}

$$
\text { I } 13 / 4 \times 171 / 2
$$

$$
183
$$

VENICE, ITALY.

$$
\text { I } 6 \times 24
$$

$$
184
$$

LANDSCAPE. 


\section{85 \\ KEENE VALLEY, ADIRON- DACKS.}

I $2 \times 18$

I 86

DURHAM, CONN.

$221 / 2 \times 281 / 2$

187

LANDSCAPE.

$17 \times 24$

JAMES P. SILO,

Auctioneer. 

SMTTHSONIAN INSTITUTION LIBRARIES

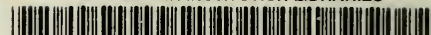

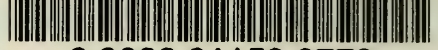

39088011596772 